\title{
Interleukin-10 Expression and Chemokine Regulation During the Evolution of Murine Type II Collagen-induced Arthritis
}

\author{
Tsuyoshi Kasama, Robert M. Strieter,; Nicholas W. Lukacs,; Pamela M. Lincoln,, Marie D. Burdick, \\ and Steven L. Kunkel* \\ Departments of *Pathology and ${ }^{\ddagger}$ Internal Medicine, Division of Pulmonary and Critical Care Medicine, The University of Michigan \\ Medical School, Ann Arbor, Michigan 48109
}

\begin{abstract}
In the enclosed study we have examined the expression and contribution of specific chemokines, macrophage inflammatory protein $1 \alpha(M I P-1 \alpha)$ and macrophage inflammatory protein 2 (MIP-2), and interleukin 10 (IL-10) during the evolution of type II collagen-induced arthritis (CIA). Detectable levels of chemotactic cytokine protein for MIP-1 $\alpha$ and MIP-2 were first observed between days 32 and 36, after initial type II collagen challenge, while increases in $\mathrm{Ll}-10$ were found between days 36 and 44. CIA mice passively immunized with antibodies directed against either MIP-1 $\alpha$ or MIP-2 demonstrated a delay in the onset of arthritis and a reduction of the severity of arthritis. On the contrary, CIA mice receiving neutralizing anti-IL-10 antibodies demonstrated an acceleration of the onset and an increase in the severity of arthritis. Interestingly, anti-IL-10 treatment increased the expression of MIP-1 $\alpha$ and MIP-2, as well as increased myeloperoxidase (MPO) activity and leukocyte infiltration in the inflamed joints. These data suggest that MIP-1 $\alpha$ and MIP-2 play a crucial role in the initiation and maintenance, while IL-10 appears to play a regulatory role during the development of experimental arthritis. (J. Clin. Invest. 1995. 95:2868-2876.) Key words: chemotactic factor - neutrophils • monocytes • chemokines • autoimmunity
\end{abstract}

\section{Introduction}

Rheumatoid arthritis (RA) is an autoimmune disease characterized by the sequestration of various leukocyte subpopulations within both the developing pannus and synovial space. The chronic nature of this disease results in multiple joint inflammation with subsequent destruction of joint cartilage and erosion of bone. While this disease has a world-wide distribution, its pathogenesis is not clearly understood (1). Type II collageninduced arthritis (CIA) ${ }^{1}$ in the mouse has proven to be a useful

Address correspondence to Steven L. Kunkel, Ph.D., Professor, Department of Pathology, M-5214 Medical Science I, Box 0602, The University of Michigan Medical School, Ann Arbor, MI 48109-0602. Phone: 313-763-6458; FAX: 313-764-2397. T. Kasama's present address is The First Department of Internal Medicine, Showa University School of Medicine, Tokyo, Japan.

Received for publication 9 December 1994 and in revised form 31 January 1995.

1. Abbreviations used in this paper: CIA, collagen-induced arthritis; MIP, macrophage inflammatory protein; MPO, myeloperoxidase.

J. Clin. Invest.

(c) The American Society for Clinical Investigation, Inc. 0021-9738/95/06/2868/09 \$2.00

Volume 95, June 1995, 2868-2876 model of RA, as it possesses many of the cell and humoral immunity characteristics found in human RA $(2,3)$. The pathogenesis of CIA is dependent upon the host's response to typeII collagen challenge and the subsequent generation of antibodies that recognizes collagen rich joint tissue $(2,3)$. The chronic activities initiated by immune complexes trigger a variety of cell-mediated and humoral events. Moreover, the recruitment and activation of neutrophils, macrophages, and lymphocytes into joint tissues and the formation of the pannus are hallmarks of the pathogenesis of both CIA and human RA. While the contribution of inflammatory leukocytes to the progression of experimental arthritis and human RA is unquestioned, the mechanisms whereby these leukocytes are recruited to the inflamed joint is still not fully known. Recently, several chemotactic cytokines (chemokines) which demonstrate a high degree of specificity for the movement of leukocyte subpopulations have been isolated and cloned. These chemokines belong to a supergene family of cytokines that are divided into two distinct groups, C-X-C and C-C, designated by the position of the first two cysteine amino acid residues $(4,5)$. The $\mathrm{C}-\mathrm{C}$ chemokines include, MIP- $1 \alpha$, MIP-1 $\beta$, RANTES, MCP-1, MCP-2, MCP-3, and I-309. The other chemokine family (C-X-C) includes, IL8, MIP-2 (murine functional homologue of IL-8), ENA-78, cleavage products of platelet basic protein (CTAP-III, $\beta$-thromboglobulin, and NAP-2), PF4, GRO $\alpha, \beta \gamma$, and IP-10. The C$\mathrm{X}-\mathrm{C}$ chemokines are mainly chemotactic for neutrophils, while the C-C chemokine family are primarily chemotactic for mononuclear cells. Recently, it has been demonstrated that IL-8, MIP$1 \alpha$, MIP- $1 \beta$, and RANTES are differentially chemotactic for lymphocyte subsets (6-9). Members of both chemokine families may play prominent roles in RA, as neutrophil and mononuclear cell elicitation and activation are prevalent in this disease.

While a number of pro-inflammatory cytokines have been studied in both human RA and murine CIA, relatively little is known regarding the production of immunomodulating cytokines, such as IL-10, during the development of this disease. Originally, interleukin 10 (IL-10) was described as a cytokine synthesis inhibitory factor produced by murine $\mathrm{Th}_{2}$ cell clones that could inhibit the synthesis of interferon- $\gamma$ by $\mathrm{Th}_{1}$ clones (10-13). Recent studies have demonstrated that IL-10 can inhibit the production of a variety of cytokines from other leukocyte populations, including IL-1, IL-6, TNF, IL-8, GM-CSF, and G-CSF, from macrophages/monocytes (14-16), and IL-1, TNF, IL-8, MIP- $1 \alpha$ and MIP- $1 \beta$, from PMNs $(17,18)$. Interestingly, exogenous $\mathrm{IL}-10$ has been found to exert suppressive effects in vivo, such as preventing endotoxin-induced lethality by inhibiting the over expression of TNF (19), and delaying the onset of autoimmunity in NZB/W F1 mice (20). Thus, IL-10 appears to possess certain immuno-regulatory activities during inflammatory/immune responses.

In the present study, we have analyzed the expression of MIP-1 $\alpha$, MIP-2, and IL-10 using a variety of parameters, in- 
cluding cytokine-specific ELISAs, immuno-histochemistry, and RT-PCR. In addition, passive immunization with neutralizing antibodies to these mediators demonstrated their contribution to the evolution of CIA. Our data supports our hypothesis that the expression of specific chemokines during the development of CIA are important pathologic factors which mediate the elicitation of blood leukocytes to the pannus and surrounding joint tissue. In addition, IL-10 appears to be an important immunomodulator of the pathogenesis of CIA via regulating the expression of pro-inflammatory cytokines, including MIP- $1 \alpha$ and MIP-2.

\section{Methods}

Animals and reagents. Male DBA/1J mice, 8-10 wk of age, were purchased from the Jackson Laboratory (Bar Harbor, ME). Chick type II collagen was purchased from Sigma Chemical Co., (St. Louis, MO). Murine recombinant IL-10, MIP-1 $\alpha$, and IFN- $\gamma$ were purchased from Pepro Tech Inc. (Rocky Hill, NJ). Murine MIP-2 was purchased from Austral Biologicals (San Roman, CA). Specific murine cytokine antisera (MIP-1 $\alpha$, MIP-2, IL-10, and IFN- $\gamma$ ) were raised in our laboratory by immunizing rabbits with recombinant murine cytokines. $F(a b)^{2}$ fragments of anti-MIP-1 $\alpha$, MIP-2, and IL-10 IgG antibody were generated using an immobilized pepsin system (Pierce Chemical Co., Rockford, IL). $50 \mu \mathrm{g} / \mathrm{ml}$ of anti-MIP-1 $\alpha$, anti-MIP-2, or anti-IL-10 antibody were capable of neutralizing $50 \mathrm{ng} / \mathrm{ml}$ of MIP- $1 \alpha, 50 \mathrm{ng} / \mathrm{ml}$ of MIP-2, and $50 \mathrm{ng} / \mathrm{ml}$ of IL-10, respectively. The antisera to murine MIP-1 $\alpha$, MIP2 , IL-10, or IFN- $\gamma$ neither cross reacted with each other nor with the following members of the chemokine family: RANTES, MCP-1, MIP$1 \beta$, platelet factor 4 (PF-4), connective tissue activating peptide III (CTAP-III), beta-thromboglobulin, NAP-2, ENA-78, GRO $\alpha$, or IP-10. All reagents were tested for endotoxin contamination using a limulus amebocyte lysate test kit (QCL-1000; Whittaker Bioproducts, Inc., Walkersville, MD). The concentration of endotoxin was consistently below $1 \mathrm{pg} / \mathrm{ml}$ in all reagents.

Induction of collagen-induced arthritis. Type II collagen-induced arthritis in mice was elicited using established methods previously described (21-23). Briefly, mice were immunized by intradermal injection of $100 \mu \mathrm{g}$ of acidified type II collagen emulsified in complete Freund's adjuvant (Difco Laboratories, Detroit, MI). Mice were boosted intradermally with $100 \mu \mathrm{g}$ of type II collagen emulsified in incomplete Freund's adjuvant (Difco Laboratories) at $\mathbf{2 1} \mathbf{d}$ after the first immunization. As controls, mice were injected with acidified complete then incomplete Freund's adjuvant.

Arthritis evaluation. Mice were observed daily for the presence of distal joint swelling and erythema. Paws were individually scored, using previously described procedures, on a scale of 0-3 based on the amount of erythema, swelling, or joint rigidity (Arthritis Index), giving a maximum score of 12 per mouse (24). The joints were also histologically evaluated for the presence of arthritic lesions. Histopathologic assessment was coded for blind observation, and a histopathologic score assigned to each joint was based upon the extent of inflammation, pannus formation, cartilage damage, and bone erosion, each using a scale of 1 (minimal) to 5 (severe) (25). Scores were combined to give a global arthritis score of a maximum of $\mathbf{2 0}$ for each mouse.

Preparation of aqueous joint extracts. Joint tissues were prepared by first removing the skin and separating the limb below the ankle joint. Joint tissues were homogenized on ice in $3 \mathrm{ml}$ lysis buffer (PBS containing: $2 \mathrm{mM}$ PMSF, and $1 \mathrm{mg} / \mathrm{ml}$ [final concentration], each of aprotinin, antipain, leupeptin, and pepstatin A) using a Polytron (Brinkmann Instruments, Westbury, NY). The homogenized tissues were then centrifuged at $2,000 \mathrm{~g}$ for $10 \mathrm{~min}$. Supernatants were sterilized with a millipore filter $(0.2 \mu \mathrm{m})$ and stored at $-80^{\circ} \mathrm{C}$ until analyzed. The extracts usually contained $0.2-1.5 \mathrm{mg}$ protein/ml, as measured by protein assay kit (Pierce Chemical Co., Rockford, IL).

Murine cytokine-specific ELISA. Murine cytokines (MIP-1 $\alpha$, MIP$2, \mathrm{IL}-10$, and IFN- $\gamma$ ) were quantified using a modification of a double ligand method, as previously described (18). Briefly, flat-bottomed 96well microtiter plates were coated with $50 \mu \mathrm{l} /$ well of rabbit anti-cytokine antibodies $\left(1 \mu \mathrm{g} / \mathrm{ml}\right.$ in $0.6 \mathrm{~mol} /$ liter $\mathrm{NaCl}, 0.26 \mathrm{~mol} / \mathrm{liter} \mathrm{H}_{3} \mathrm{BO}_{4}$, and $0.08 \mathrm{~N} \mathrm{NaOH}, \mathrm{pH} \mathrm{9.6)}$ for $16 \mathrm{~h}$ at $4^{\circ} \mathrm{C}$, and then washed with PBS, $\mathrm{pH} 7.5,0.05 \%$ Tween 20 (wash buffer). Nonspecific binding sites on microtiter plates were blocked with 2\% BSA in PBS and incubated for $90 \mathrm{~min}$ at $37^{\circ} \mathrm{C}$. Plates were rinsed four times with wash buffer, and diluted aqueous joint samples $(50 \mu \mathrm{l})$ were added, followed by incubation for $1 \mathrm{~h}$ at $37^{\circ} \mathrm{C}$. Plates were washed four times with wash buffer, then $50 \mu \mathrm{l} /$ well of biotinylated rabbit anti-IL-10 was added and incubated for $30 \mathrm{~min}$ at $37^{\circ} \mathrm{C}$. After washing of plates, chromogen substrate was added. The plates were incubated at room temperature to the desired extinction, and the reaction terminated with $50 \mu \mathrm{l} /$ well of $3 \mathrm{M} \mathrm{H}_{3} \mathrm{SO}_{4}$ solution, and were read at $490 \mathrm{~nm}$ in an ELISA reader. This ELISA method consistently had a sensitivity limit of $\sim 30 \mathrm{pg} / \mathrm{ml}$.

Histopathology and immunohistochemical localization of cytokines in joint tissues. Joint specimens were fixed in $4 \%$ paraformaldehyde for $24 \mathrm{~h}$ before transfer to $70 \%$ ethanol. Specimens were decalcified for 1 to $2 \mathrm{~h}$ in a RDO solution (active reagent; hydrochloric acid; APEX engineering products corp., Plainfield, IL), embedded in paraffin, and stained with hematoxylin and eosin. For immunohistochemical localization of cytokines, paraffin-embedded specimens were deparaffinized with xylene followed by rehydration in $100,95,70$, and $50 \%$ ethanol. Before staining, the slides were fixed for $30 \mathrm{~min}$ in ice-cold acetone. Endogenous peroxidase activity was quenched by incubating the slides for $30 \mathrm{~min}$ in absolute methanol and 3\% hydrogen peroxide. The tissue sections were blocked with normal goat serum for $2 \mathrm{~h}$ at $37^{\circ} \mathrm{C}$, and then incubated with optimal concentrations of purified rabbit anti-murine cytokine (MIP-1 $\alpha$, MIP-2, and IL-10) antibodies or normal rabbit purified IgG for $2 \mathrm{~h}$ at $37^{\circ} \mathrm{C}$. After washing three times with PBS, the tissue sections were incubated with secondary biotinylated goat anti-rabbit IgG (supersensitive reagent; BioGenex, San Ramon, CA). The slides were then treated with streptavidin conjugated to peroxidase for $30 \mathrm{~min}$ at $37^{\circ} \mathrm{C}$, rinsed three time with PBS, overlaid with $300 \mathrm{ml}$ of equal volumes of 3-amino-9-ethylcarbazole $40 \mathrm{mg} / \mathrm{ml}$ in $N, N$-dimethylformamide (Sigma Chemical Co.), and treated with 3\% hydrogen peroxide in $0.1 \mathrm{M}$ sodium acetate for $5-15 \mathrm{~min}$ at $37^{\circ} \mathrm{C}$ to allow color development. After rinsing with distilled water, the slides were stained with Mayer's hematoxylin. Specificity was demonstrated in these studies by competitive inhibition. Preincubation of anti-cytokine antibody with excess recombinant, exogenous specific cytokine before immunostaining resulted in a complete loss of staining.

Isolation of whole joint RNA and reverse transcriptase-polymerase chain reaction ( $R T-P C R$ ). Total RNA from joint tissues was isolated using previously described techniques (18). Briefly, $3 \mathrm{ml}$ of guanidine isothiocyanate solution containing $25 \mathrm{mM}$ Tris, $\mathrm{pH}$ 8.0, 4.2 M guanidine isothiocyanate, $0.5 \%$ Sarkosyl, and $0.1 \mathrm{M} 2-\mathrm{ME}$ was added to each joint sample. After homogenization using a Polytron, the above suspension was added to a solution containing an equal volume of $100 \mathrm{mM}$ Tris, pH 8.0, $10 \mathrm{mM}$ EDTA, and 1.0\% SDS. The mixture was then extracted with chloroform-phenol and chloroform-isoamyl alcohol. The RNA was alcohol-precipitated and the pellet dissolved in diethyl pyrocarbonatetreated $\mathrm{H}_{2} \mathrm{O}$.

RT-PCR was performed as previously descried (26) Briefly, $5 \mu \mathrm{g}$ of total RNA from joint sample was reverse transcribed into cDNA utilizing M-MLV reverse transcriptase (GIBCO BRL, Grand Island, NY). The cDNA was then amplified using specific primers for murine MIP-1 $\alpha$, MIP-2, IL-10, and GAPDH, the latter as an internal control. The primers were 5'-GCC-CTT-GCT-GTT-CTT-CTC-TGT (sense), and 5'-GGC-AAT-CAG-TTC-CAG-GTC-AGT (anti-sense) for murine MIP-1 $\alpha$ (27), 5'-GCT-GGC-CAC-CAA-CCA-CCA-GG (sense) and 5'AGC-GAG-GCA-CAT-CAG-GTA-CG (anti-sense) for murine MIP-2 (28), 5'-GCT-ATG-TTG-CCT-GCT-CTT-AC (sense), and 5'-GCCTGG-GGC-ATC-ACT-TCT-AC (anti-sense) for IL-10 (12), 5'-GGCATC-CGG-ACG-TTC-TAC-GG (sense) and 5'-ATG-GTG-AAG-GTCGGT-GTG-AAC (anti-sense) for GAPDH (29). Amplifications were performed in $4 \mathrm{mM} \mathrm{MgCl}, 50 \mathrm{mM} \mathrm{KCl}, 10 \mathrm{mM}$ Tris- $\mathrm{HCl}$ (pH 8.3), 0.2 $\mathrm{M}$ of each deoxynucleotide triphosphate, $2.5 \mathrm{U} / \mu \mathrm{l} \mathrm{Taq}$ DNA polymerase, $4 \mu \mathrm{g} / \mathrm{ml}$ of each specific primer, and $1 \mu \mathrm{l}$ of the reverse transcribed 


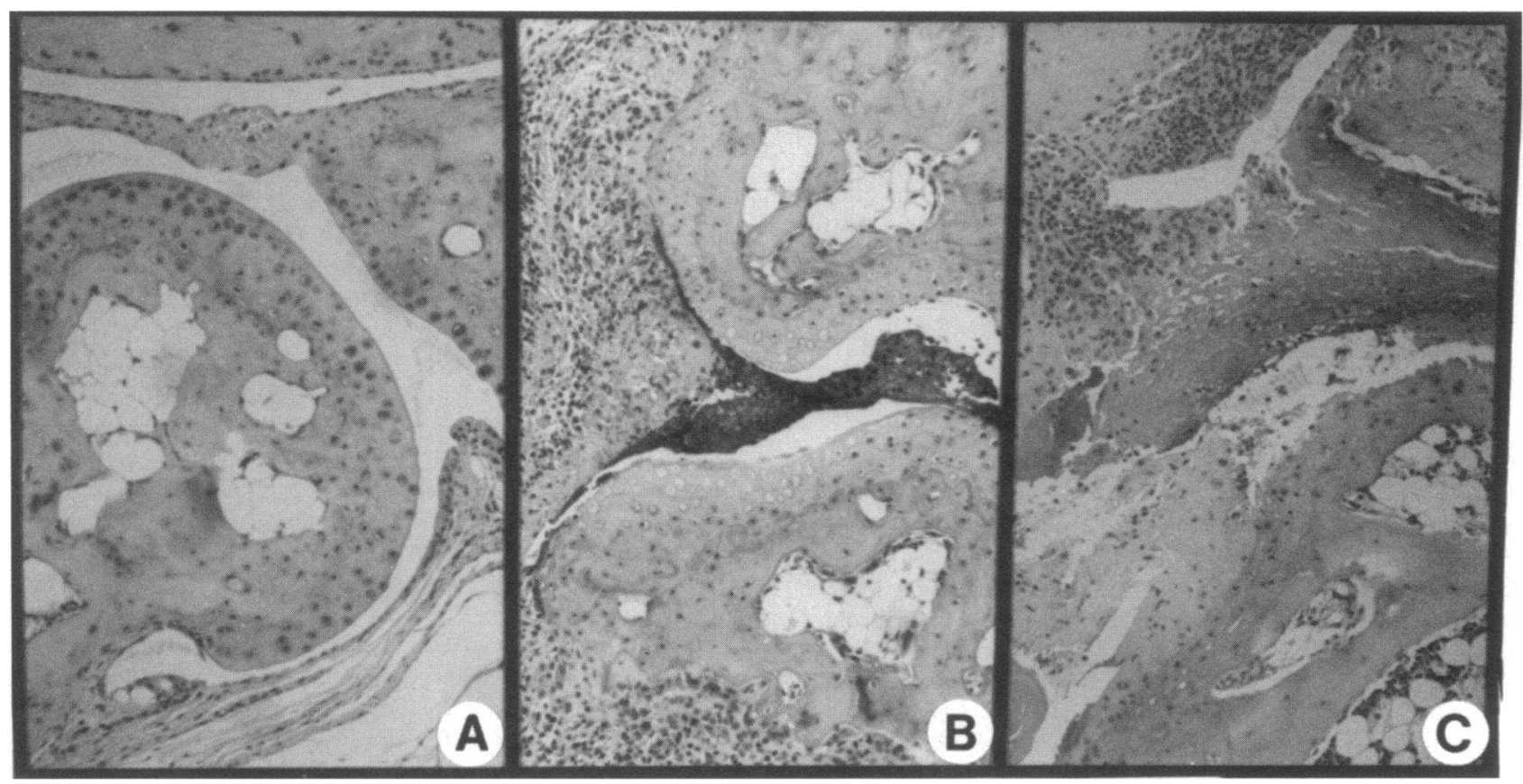

Figure 1. Histological demonstration of normal joint $(A)$, and arthritic joints taken at $36 \mathrm{~d}(B)$, and $68 \mathrm{~d}(C)$ after primary immunization with type II collagen. The sections from the arthritic joints demonstrate significant pannus formation with infiltration of neutrophils, and mononuclear cells, as well as cartilage destruction and bone erosion. ( $\mathrm{H} \& \mathrm{E}$ stain, $\times 100)$.

cDNA samples. The cDNA was amplified in an automated thermal cycler (Perkin Elmer Cetus, Norwalk, CT) at $9^{\circ} \mathrm{C}$ for $30 \mathrm{~s}, 65^{\circ} \mathrm{C}$ for 45 s, $72^{\circ} \mathrm{C}$ for $75 \mathrm{~s}$. Amplification was stopped at 35 cycles. After amplification, the samples $(20 \mu \mathrm{l})$ were separated on $2 \%$ agarose gel containing $0.3 \mu \mathrm{g} / \mathrm{ml}$ of ethidium bromide. The DNA were visualized and photographed using UV transillumination.

Measurement of serum anti-collagen antibody titers. Measurement of anti-collagen IgG was preformed using an ELISA, as described previously $(21,30)$. Briefly, microtiter plates were coated with $50 \mu 1 /$ well of chicken type II collagen ( $20 \mu \mathrm{g} / \mathrm{ml}$ ), blocked, and incubated with serially diluted serum samples. Bound IgG was detected by incubation with $50 \mu \mathrm{l} /$ well of peroxidase-conjugated goat anti-mouse IgG, followed by chromogen substrate. Plates were read at $490 \mathrm{~nm}$ in an ELISA reader. A standard, consisting of pooled mouse anti-type II antiserum, and normal mouse serum were titered on each plate to ensure uniformity of the assay system.

Measurement of IFN- $\gamma$ responses. Gamma-interferon production was determined from spleen cells and inguinal lymph node cells from

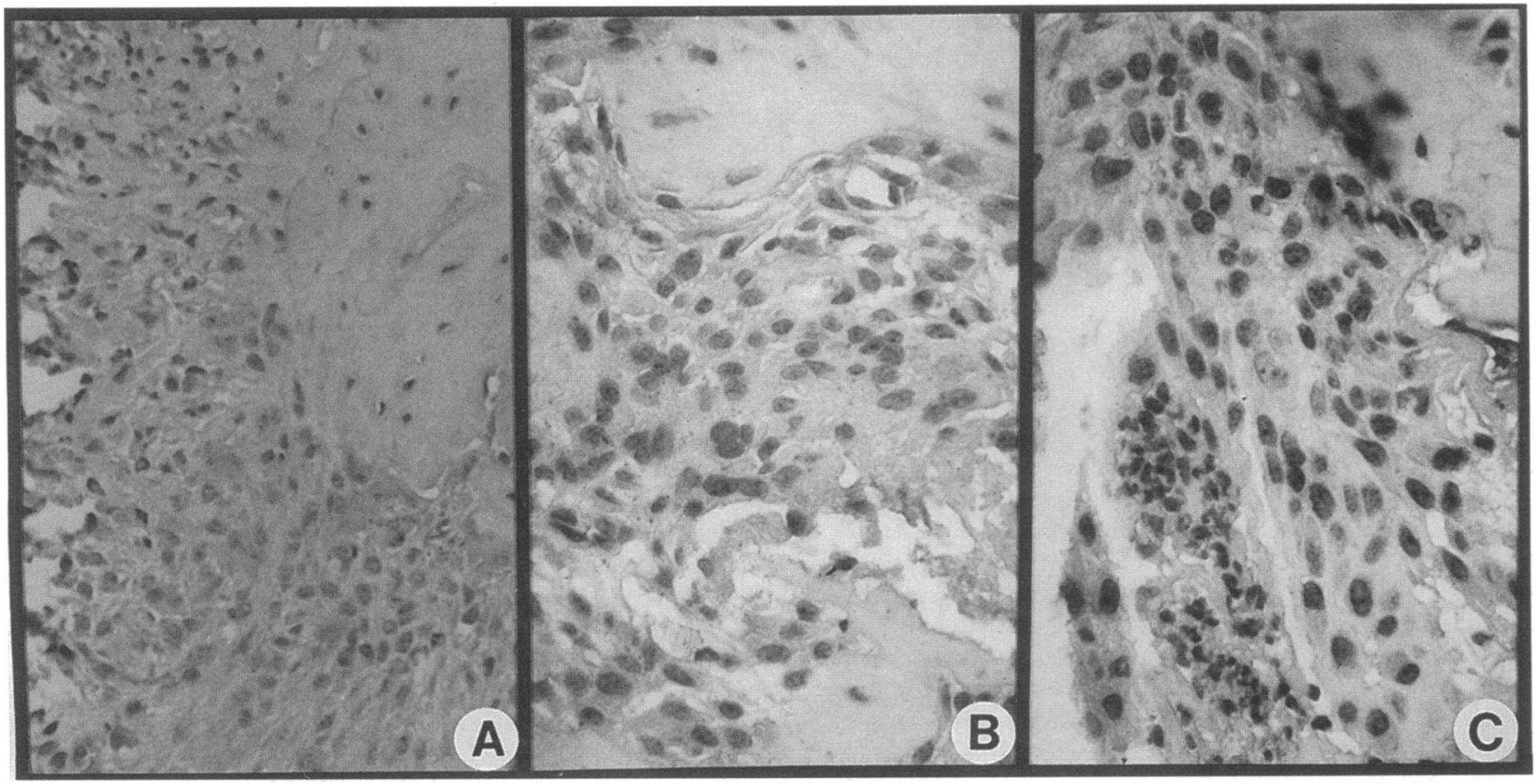

Figure 2. Immunolocalization of MIP-1 $\alpha$ and MIP-2 in joint tissue form chronic arthritis. Paraffin-embedded specimens were deparaffinized and immunostained for MIP-1 $\alpha(B)$ and MIP-2 $(C)$. A is a control using pre-immune serum. $(\times 400)$. 

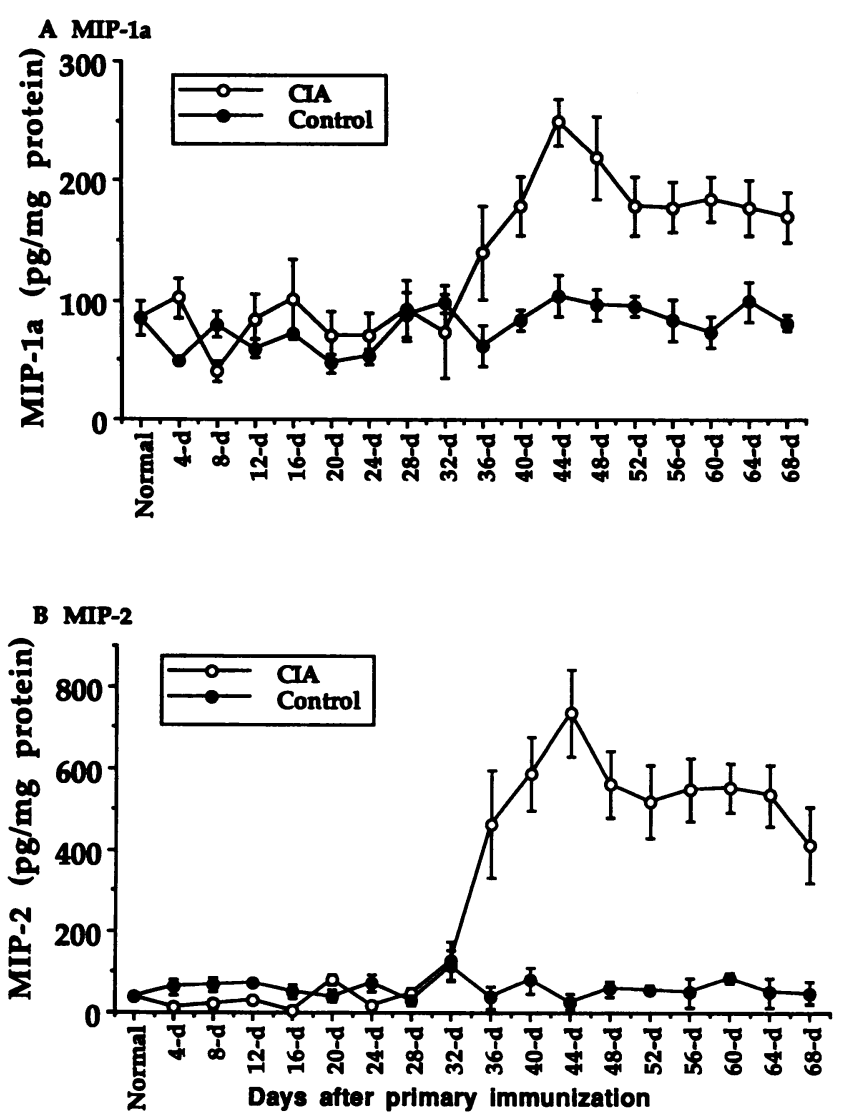

Figure 3. Kinetic expression of MIP-1 $\alpha$ and MIP-2 antigen from joint aqueous extracts, as measured by cytokine specific ELISAs. Samples were taken every fourth day from time of initial immunization (mean \pm SE of 12 joint tissue samples per time point $X 3$ studies). Data differed significantly between the group of controls and type II collagenimmunized mice on days 40 and thereafter $(P<0.05$ for MIP-1 $\alpha)$ and on day 36 and thereafter $(P<0.05$, MIP-2), respectively.

either mice treated with either anti-IL-10 sera or with preimmue sera (31). Cells were obtained by dissection and single cells $\left(5 \times 10^{6}\right.$ cells/ $\mathrm{ml}$ ) were suspended in RPMI 1640 (GIBCO BRL) supplemented with $2 \mathrm{mM}$ L-glutamine, $25 \mathrm{mM}$ Hepes, $100 \mathrm{U} / \mathrm{ml}$ penicillin, $100 \mu \mathrm{g} / \mathrm{ml}$ streptomycin (Hazelton Research Products, Lenexa, KS), and 5\% heatinactivated fetal calf serum (FCS) (GIBCO BRL). Cells were seeded in triplicate into 96-well flat-bottom plates with or without collagen (25 $\mu \mathrm{g} / \mathrm{ml}$ of native type II collagen, or $10 \mu \mathrm{g} / \mathrm{ml}$ of denatured type II collagen) in a total volume of $0.2 \mathrm{ml} /$ well. Supernatants were collected after 72 -h incubation at $37^{\circ} \mathrm{C}$ in humidified $5 \% \mathrm{CO}_{2}$, and IFN- $\gamma$ production was measured by cytokine-specific ELISA.

Myeloperoxidase (MPO) assay. Neutrophil infiltration to the inflamed joints was indirectly quantitated using an MPO assay, as previously described for neutrophil elicitation (32). Tissue was prepared as described above and placed in a $50 \mathrm{mM}$ phosphate buffer $(\mathrm{pH}=6.0)$ with 5\% hexadecyltrimethyl ammonium bromide (Sigma Chemical Co.). Joint tissues were homogenized, sonicated, and centrifuged at 12,000 g for $15 \mathrm{~min}$ at $4^{\circ} \mathrm{C}$. Supernatants were assayed for MPO activity using a spectrophotometric reaction with O-dianisidine hydrochloride (Sigma Chemical Co.) at $460 \mathrm{~nm}$.

Statistical analysis. Data were analyzed by Macintosh ${ }^{\circledR}$ II computer using a statistical software package (Statview II; Abacus Concept, Inc., Berkeley, CA) and expressed as mean \pm SEM. Differences between cytokine levels, arthritis severity, MPO activity, and histopathologic score were compared by analysis of variance. Arthritis incidence was analyzed by the Mann-Whitney $U$ test. Differences were considered significant if $P$ values were $<0.05$.

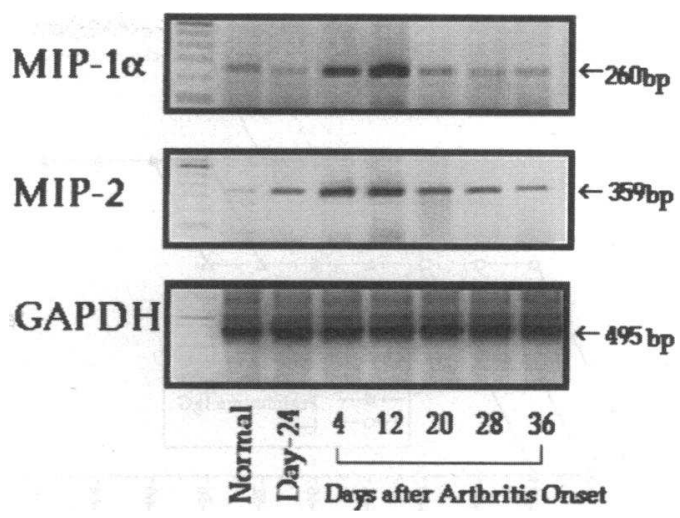

Figure 4. Kinetic analysis of MIP- $1 \alpha$ and MIP-2 mRNA by RT-PCR amplification. Whole RNA was isolated from joint tissues at specific time points, mRNA reversed transcribed and amplified using cytokinespecific primers. GAPDH primers were used as an internal control. Data are representative of three individual experiments.

\section{Results}

Development of experimental arthritis. Arthritis developed in $95 \%$ of the mice by $6 \mathrm{wk}$ after the primary immunization with type II collagen. The histopathology of joints from experimental animals without and with arthritis is shown in Fig. $1 A$ and Fig. $1, B$ and $C$, respectively. Synovial proliferation with pannus formation, cartilage erosion, and bone degradation can clearly be observed by $36 \mathrm{~d}$ after the initial primary immunization (Fig. $1 B$ ), as compared with normal joints (Fig. $1 A$ ). In addition, the infiltration of PMNs and mononuclear cells (macrophages and lymphocytes) can be observed at this time with exudation of cells into the joint space (Fig. $1 \mathrm{~B}$ ). By $68 \mathrm{~d}$ after the primary immunization, joint pathology revealed significant bone erosion. This was accompanied with significant pannus formation and cartilage destruction (Fig. $1 C$ ). This longitudinal histologic pattern of arthritis is consistent with the joint pathology associated with human rheumatoid arthritis.

Immunolocalization and longitudinal expression of chemokines during experimental arthritis. The above histological pattern of joint pathology appeared to be correlated with the influx of leukocytes into the joint, joint space, and surrounding tissue. Therefore, we initiated studies to assess the localization of chemokines to inflamed joints and determine the longitudinal expression patterns of these chemotactic cytokines during the development of CIA. As shown in Fig. 2, immunolocalization of both MIP- $1 \alpha$ and MIP- 2 could be identified in association with infiltrating macrophage-like cells, chondrocytes, and fibroblast-like cells in the chronically inflamed joint tissues (Fig. 2, $B$ and $C$ ). However, tissue sections stained with preimmune, control serum in a similar fashion demonstrated little nonspecific staining for murine cytokines (Fig. 2 A). Immunohistochemical assessment of normal, non-inflamed joints failed to detect any constitutive expression of MIP-2 or MIP-1 $\alpha$. In additional studies, the temporal expression pattern of joint MIP$1 \alpha$, and MIP-2 was assessed by ELISA and was found to correlate with the development of arthritis. Mice with or without type II collagen immunization were sacrificed every 4 days and joint tissue prepared for cytokine analysis. As shown in Fig. 3, both MIP- $1 \alpha$ and MIP-2 were expressed in a kinetic fashion as joint disease progressed. MIP- $1 \alpha$ and MIP- 2 were first identified $\sim 32 \mathrm{~d}$ after the initial immunization protocol. The elevation in 


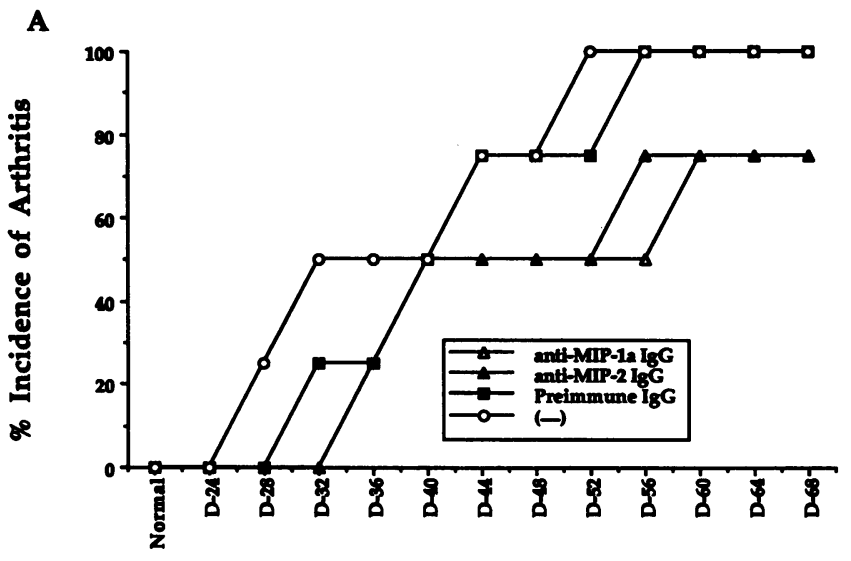

B

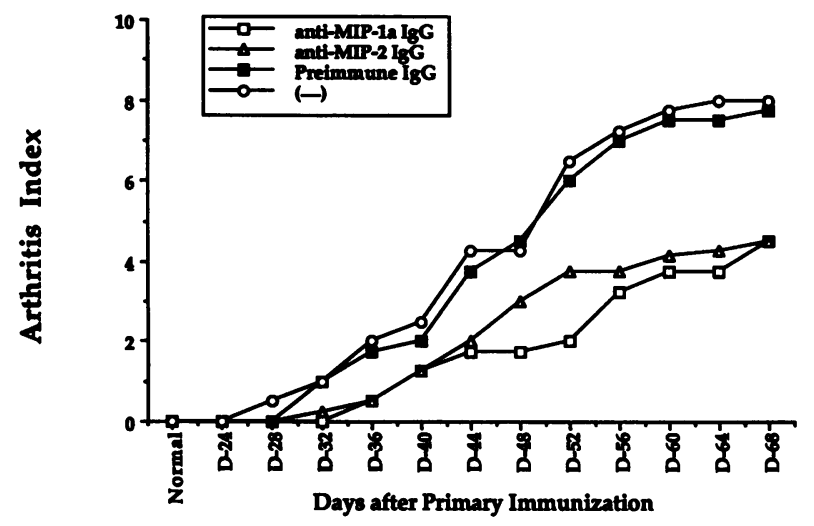

Figure 5. Kinetic study on the effects of either neutralizing anti-MIP$1 \alpha$ or MIP- 2 on the development of arthritis incidence $(A)$ and severity $(B) . \mathrm{F}(\mathrm{ab})_{2}$ fragments of anti-MIP-1 $\alpha$, MIP-2, or control were administered every other day from 24-32 d after primary immunization. Data represents a total of five mice per time point. The incidence and severity differed significantly between the group of control and anti-MIP-1 $\alpha$ or anti-MIP-2 sera treated mice on days 44 and thereafter $(P<0.05)$ and on days 56 and thereafter $(P<0.05)$, respectively.

chemokine protein levels correlated with a significant leukocyte infiltrate, as shown in the histopathology in Fig. 1. The amount of MIP- $1 \alpha$ and MIP- 2 antigen from mice with arthritis reached maximum expression 40-44 d after the primary immunization and then gradually decreased. An increase in cytokines from control mice (immunized without type II collagen) was not identified throughout the entire experimental period. These studies demonstrate that MIP- $1 \alpha$ and MIP-2 are both expressed in a kinetic manner at sites of inflamed joints and likely play a crucial role in the induction and maintenance of experimental arthritis.

Kinetics of chemokine mRNA expression during the evolution of experimental arthritis. To determine whether the expression of antigenic MIP- $1 \alpha$ and MIP-2 was accompanied by similar increases in steady-state mRNA levels, we assessed their expression from joint tissue using RT-PCR. As shown in Fig. 4 , both MIP- $1 \alpha$ and MIP-2 mRNA were significantly expressed in joint tissue during the evolution of experimental arthritis. Interestingly, mRNA for MIP-2 was first observed $12 \mathrm{~d}$ after primary immunization and continued to be expressed during the study period (out to day 60), while mRNA for MIP-1 $\alpha$ was first significantly expressed at day 36 and diminished after day 44 .
A

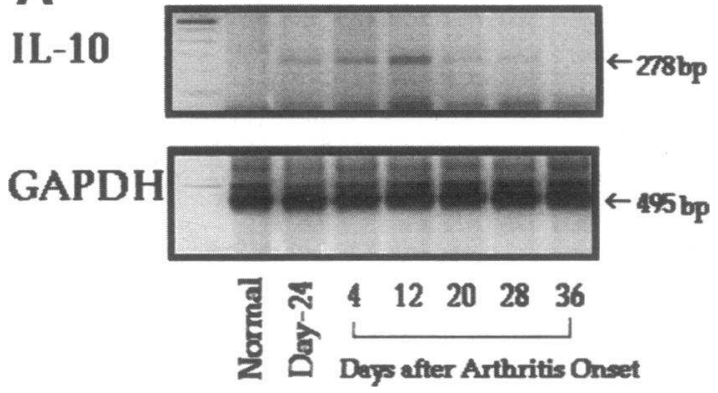

\section{B IL-10}

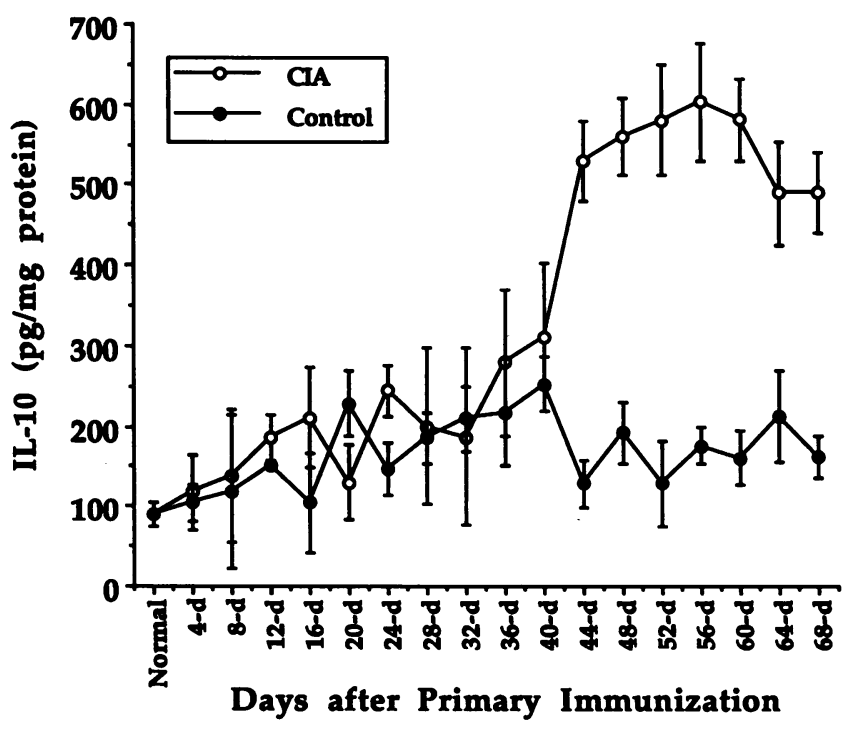

Figure 6. Kinetic assessment of IL-10 mRNA and protein during the initiation and maintenance of chronic arthritis. Detection of IL-10 mRNA $(A)$ was determined by RT-PCR at the designated time points and represents data from three separate studies. IL-10 antigen was determined by cytokine specific ELISA (mean \pm SE of 12 joint tissue samples per time point X 3 studies). Data differed significantly between the group of control and type II collagen-immunized mice on days 44 and thereafter $(P<0.05)$.

Chemokine mRNA expression was not found in control mice at any time points after primary immunization (data not shown).

The effects of passive immunization with neutralizing chemokine antibodies on the evolution of experimental arthritis. The above observations demonstrate that steady-state mRNA and protein levels for both MIP- $1 \alpha$ and MIP- 2 are temporally associated with the recruitment of leukocytes into inflamed joints. To determine the potential contribution of these chemokines to the developing inflammation, mice were passively immunized with control $F(a b)_{2}$ fragments or neutralizing $F(a b)_{2}$ directed against either MIP- $1 \alpha$ or MIP-2. The $\mathrm{F}(\mathrm{ab})_{2}$ fragments were used to eliminate the potential influence of Fc-dependent activation that may occur during the formation of chemokine/antichemokine immune complexes, thus altering the development of CIA $(33,34)$. Mice were intraperitoneally treated with $1 \mathrm{mg}$ of neutralizing $\mathrm{F}(\mathrm{ab})_{2}$ fragment every other day from days 2432. The therapeutic effect of passive immunization on the incidence and severity of arthritis is shown in Fig. 5. Depletion of either MIP- $1 \alpha$ or MIP- 2 had a beneficial effect on reducing the 


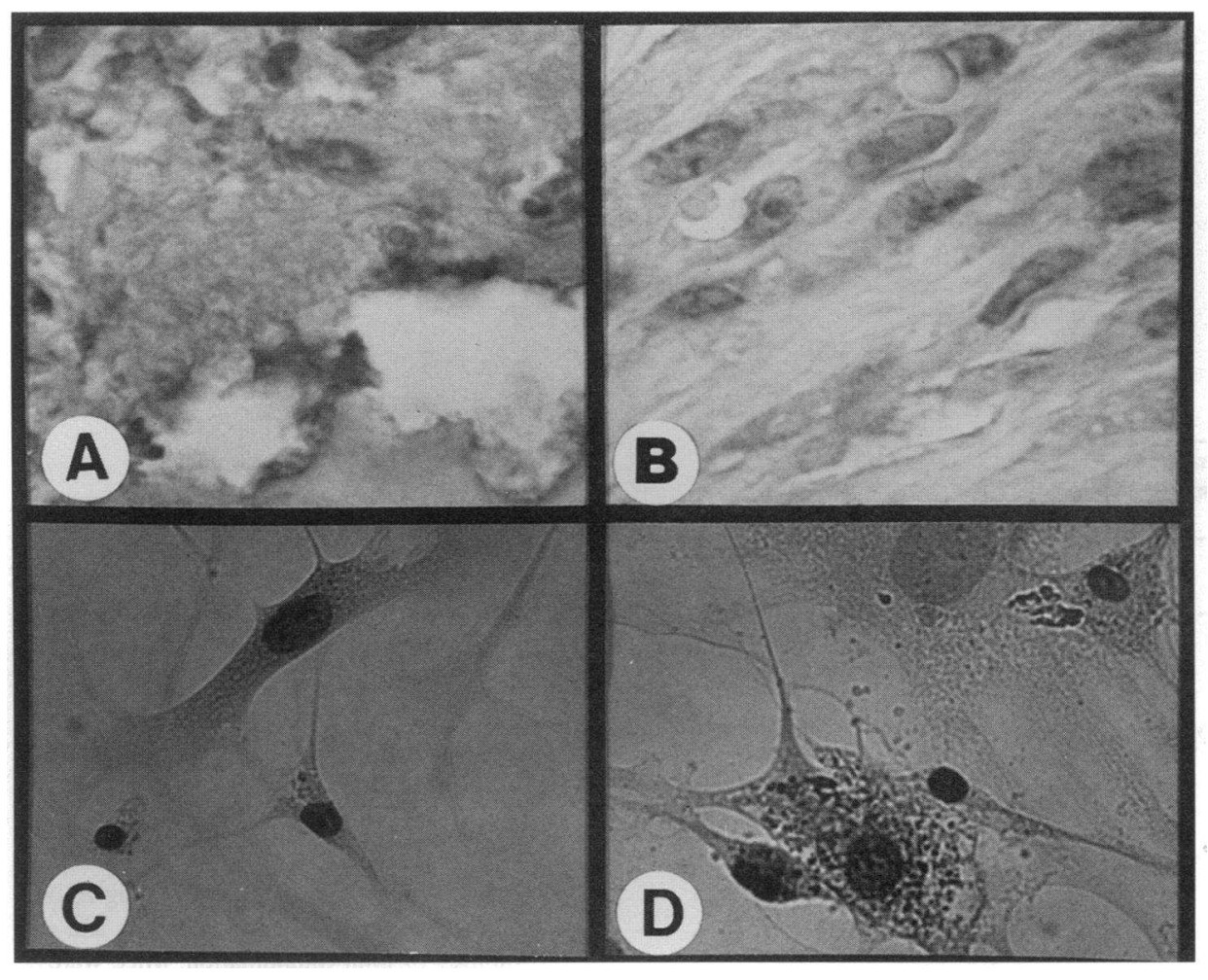

Figure 7. Immunolocalization of IL-10 from synovial tissue and isolated synovial fibroblasts at day 56 after primary immunization. $A$ and $B$ represent synovial tissue immunostained with pre immune serum and anti-IL-10 serum, respectively. $C$ and $D$ represent isolated synovial fibroblasts stained with pre immune serum and anti-IL-10 serum, respectively. incidence of arthritic, as well as reducing the amount of joint erythema, swelling, and rigidity (Arthritic Index).

The temporal production and contribution of IL-10 to the development of experimental arthritis. A number of in vitro and in vivo studies have identified important regulatory aspects of IL-10 with regard to controlling the production of specific cytokines $(13-17,35)$. In addition, we have identified IL-10 as an important cytokine involved in regulating the levels of both steady-state chemokine mRNA and protein (18). Therefore, we examined whether IL-10 was expressed in a time-dependent manner during the development of CIA. In initial experiments, the kinetic expression of IL-10 steady-state mRNA and protein was assessed (Fig. 6, $A$ and $B$ ). Peak levels of IL-10 protein were identified at approximately day 44 after primary challenge with type II collagen. The kinetic pattern for steady-state levels of IL-10 mRNA was substantiated by RT-PCR, which demonstrated a zenith at approximately day 44 . The time frame for the expression of IL-10 was coincident with the developing pathology of the arthritic joint. Interestingly, IL-10 was immunolocalized to infiltrating macrophage-like cells, chondrocytes, and fibroblast-like cells. A typical immunostaining pattern for tissue synovial fibroblasts and cultured synovial fibroblasts is shown in Fig. 7. To confirm a contributing role for IL-10 during the evolution of joint inflammation, we next examined the effects of passive immunization using neutralizing $\mathrm{F}(\mathrm{ab})_{2}$ antiIL-10 on the development of experimental arthritis (Fig. 8). Mice were treated intraperitoneally with either $1 \mathrm{mg}$ of antiIL-10 or control $\mathrm{F}(\mathrm{ab})_{2}$ fragments every other day from days 24-32 post immunization with type II collagen. Mice treated with anti-IL-10 demonstrated a significant acceleration of joint inflammation, as identified by an earlier appearance in the incidence of arthritis and a greater arthritis index, as compared to controls (Fig. 8, $A$ and $B$ ). We next assessed potential mechanisms whereby passive immunization with anti-IL-10 could increase the severity of experimental joint inflammation. Mice passively immunized, using the above protocol, were sacrificed at day-48 post primary immunization and joints assessed for histological alterations, myeloperoxidase (MPO) activity, and chemokine levels. The histopathology of joints from animals treated with anti-IL-10 antibody showed more severe cartilage and bone destruction, as well as severe pannus formation and fibroblast proliferation than controls. An increase in the severity of the joint inflammation caused by anti-IL-10 treatment was also demonstrated by a histopathologic scoring system and the levels of MPO (Fig. 8, $C$ and $D$ ). Moreover, both MIP- $1 \alpha$ and MIP-2 expression in the joint from mice treated with anti-IL10 sera at day -48 were augmented, as compared with the other two control groups (Fig. 9). As additional controls, we found no significant effect on either anti-collagen antibody titers or IFN$\gamma$ production between anti-IL-10 treated mice and controls (data not shown). Taken together, our results suggest that MIP-1 $\alpha$ and MIP-2 are important for the initiation and maintenance of experimental joint inflammation. In addition, endogenous IL-10 likely plays a crucial role in this model by regulating the expression of inflammatory mediators, including MIP-1 $\alpha$ and MIP-2.

\section{Discussion}

Rheumatoid arthritis is one of the most common inflammatory joint diseases, possessing a world-wide distribution. In spite of a large research effort, the pathogenesis of this disease is not entirely clear. However, it is known that the progression of the disease is characterized by the presence of inflammatory cells in both the granuloma-like pannus and the joint fluid followed by cartilage destruction and bone erosion. Interestingly, the active inflammatory stage of arthritis shares a number of common histologic features of chronic inflammation, including the organized focal accumulation of mononuclear cells in the developing pannus, proliferation of fibroblast-like synovial cells, and injury to the surrounding tissue. While the proliferation of synovial cells 
A

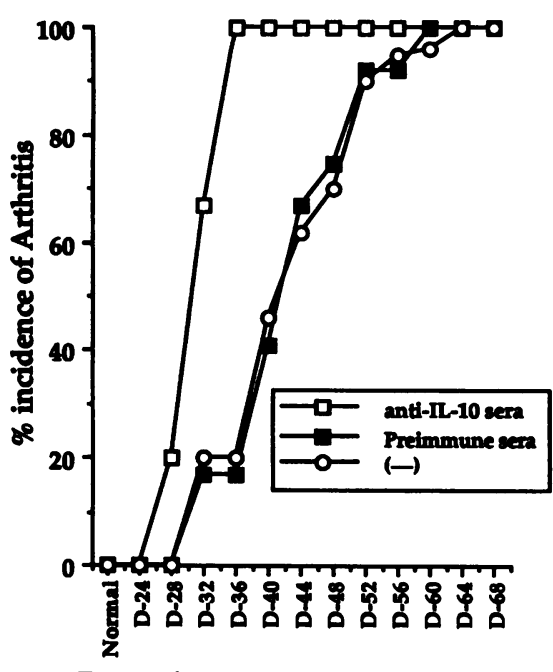

Days after Primary Immunization

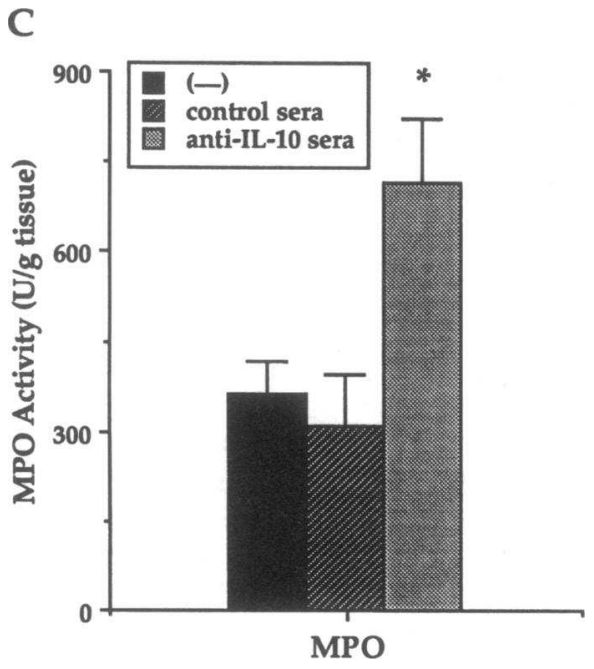

B

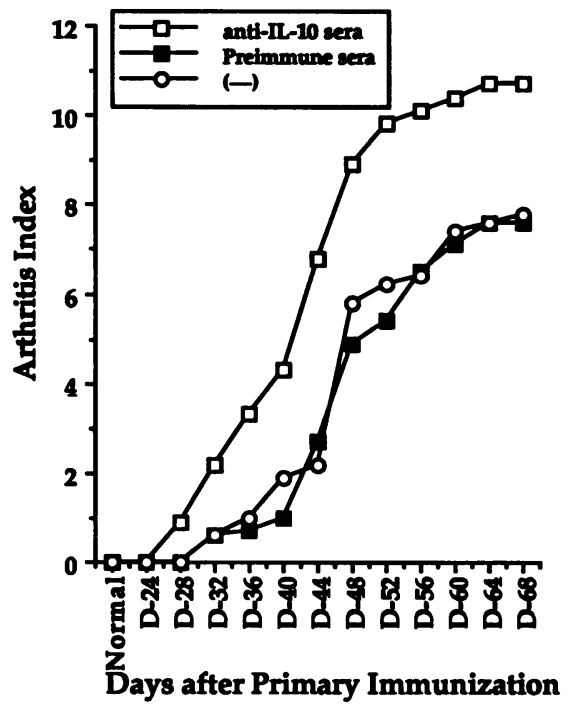

D

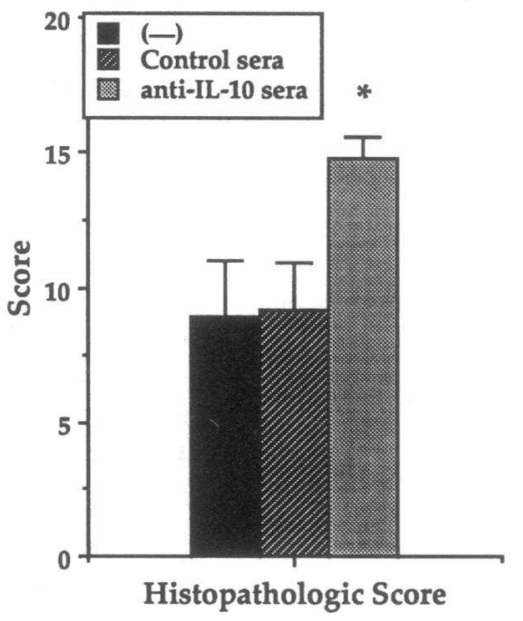

Figure 8. The effects of neutralizing $\mathrm{IL}-10$ antibody on the incidence, severity, and pathology of joint inflammation. Mice were passively immunized with either control or anti-IL-10 antibody, as described, and joints were assessed for the incidence of arthritis $(A)$, severity of arthritis $(B)$, levels of MPO activity $(C)$, and the histologic score $(D)$. MPO and histologic score were performed at day 48. Data represents six mice per time. The incidence an severity differed significantly between the group of control and antiIL-10 sera treated mice form days 32-48 ( $P$ $<0.05$ ). Levels of MPO activity and the histologic score differed significantly between the groups of control and anti-IL-10 sera treated mice on days $48(P<0.05)$. and the infiltration of leukocytes are fundamental events in the development of joint inflammation, it is difficult to longitudinally examine the mediators important to the initiation and maintenance of this pathologic cascade in human arthritis. Therefore, it is necessary to establish and characterize experimental animal models to assess cellular and molecular events that contribute to the pathogenesis of joint inflammation. Interestingly, type-II collagen-induced arthritis in the mouse has proven to be a useful model, as it possesses many of the cellular and humoral immune events found in human rheumatoid arthritis.

While $\mathrm{T}$ cell and antibody responses against type II collagen are a crucial event for the initiation of CIA $(2,36)$, it has been demonstrated that several cytokines also appear to direct cellto-cell communication in a cascade fashion during the progression of CIA. These cytokines include: IL-1 $(30,37,38)$, TNF$\alpha(24,39,40)$, IL-6 (41), TGF- $\beta$ (40), and IFN- $\gamma(42,43)$. The data presented in this report demonstrates that chemokines (MIP-1 $\alpha$ and MIP-2) and IL-10 are also expressed at sites of inflamed joints and these cytokines likely contribute in different capacities to the evolution of chronic joint inflammation. Our longitudinal analyses demonstrate that chemokine expression is observed coincident with the histopathologic observation of leukocyte accumulation. Furthermore, passive immunization with neutralizing antibodies to either MIP- $1 \alpha$ or MIP- 2 resulted in an attenuation of the inflammation, while anti-IL-10 antibodies augmented the arthritic response.

A number of recent studies have demonstrated that the recruitment of cells into an area of inflammation may be mediated not only by C5a, leukotrienes, platelet activating factor, or bacterial-derived peptides, but also by a novel group of small proteins with relatively specific chemotactic activity for leukocyte subpopulations. These small molecular weight polypeptides are synthesized by a variety of cells and belong to a novel supergene family of inflammatory mediators which share substantial homology via four conserved cysteine amino acid residues (4, 5). In one family, the first two cysteine amino acids are in juxtaposition, and are referred to as $\mathrm{C}-\mathrm{C}$ chemokines. This family includes MIP- $1 \alpha$, MIP-1 $\beta$, RANTES, MCP-1, MCP-2, MCP-3, and I-309. Recently, it has been demonstrated that MCP-1, MIP- $1 \alpha$, MIP- $1 \beta$, and RANTES are differentially chemotactic for lymphocyte subsets (6-9). The other chemokine family (C-X-C) have their first two cysteines separated by an additional amino acid residue, this family includes, IL-8, MIP2 (a murine functional homologue of human IL-8), ENA-78, 


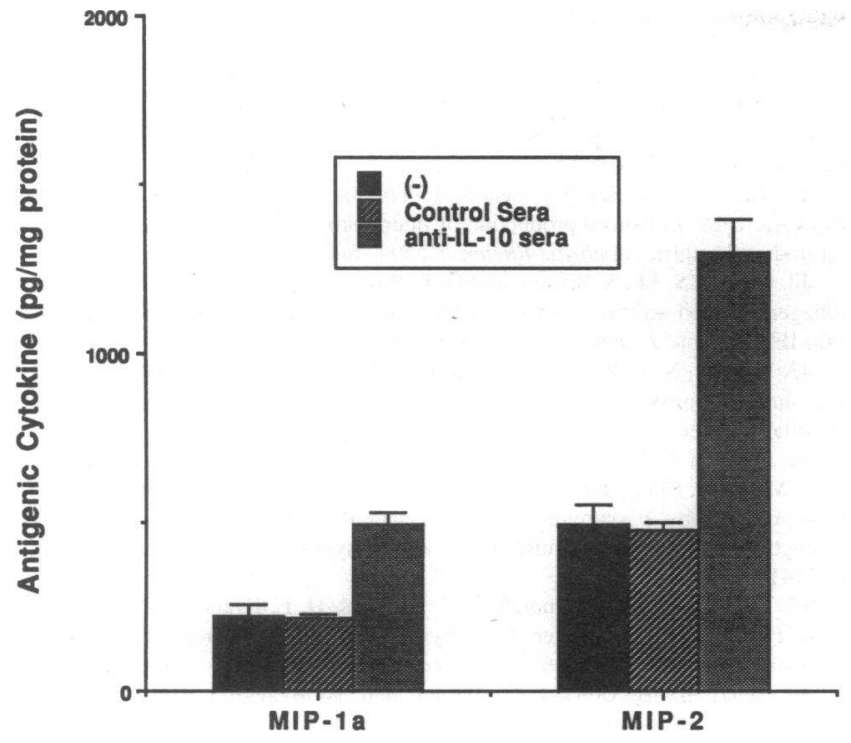

Figure 9. The effect of neutralizing anti-IL-10 antibody on chemokine expression during CIA development. Animals were either not treated, treated with control antibodies, or anti-IL-10 antibodies, as described. At day 48 after immunization, joint tissue from six mice from each group were assessed for MIP-1 $\alpha$ and MIP-2 levels by cytokine specific ELISAs. Levels MIP- $1 \alpha$ and MIP- 2 differed significantly between the groups of control and anti-IL-10 sera treated mice on days $48(P<0.05)$.

CTAP-III, $\beta$-thromboglobulin, NAP-2, PF4, GRO, and IP-10. The C-X-C chemokine family is mainly chemotactic for neutrophils, while members of the C-C chemokines possess chemotactic activity for mononuclear cells (lymphocytes and monocytes). Since the recruitment of neutrophils, macrophages, and lymphocytes into joint tissue and formation of the pannus are hallmarks of both CIA and human rheumatoid arthritis, it is important to determine the contribution of chemokines in the progression of this experimental model of human rheumatoid arthritis. Our laboratory and others have demonstrated that several chemokines, including IL-8, MCP-1, RANTES, and MIP-1 $\alpha$, are expressed in tissue from the inflamed joints of human rheumatoid arthritis (44-50).

While chemokines and other cytokines are known to play a pro-inflammatory role in the development of chronic inflammation, it has been reported that IL-10 may play an important regulatory role during the initiation and maintenance of inflammation $(19,51,52)$. Many in vivo studies suggest that IL-10 can block the expression of proinflammatory cytokines, including IL- 1 and TNF- $\alpha$, which would corroborate a number of in vitro studies $(15,16,53)$. Our laboratory and others have reported that IL-10 can inhibit the production and expression of chemokines, including IL-8, MIP- $1 \alpha$, and MIP- $1 \beta$ from human monocytes and neutrophils $(17,18,53)$. Furthermore, IL-10 appears to augment the release of cytokine modulating proteins, such as soluble TNF receptor, and interleukin-1 receptor antagonist protein $(54,55)$. Interestingly, studies have demonstrated that the soluble TNF receptors and the interleukin-1 receptor antagonist can prevent the development of CIA $(25,39,56)$. Although the above studies demonstrate that IL-10 may act as a protective cytokine during the evolution of an inflammatory reaction and $\mathrm{IL}-10$ is expressed by human synovium $(57,58)$, the contribution of chemokines and IL-10 to the arthritic response is not clear. However, it appears that the balance of pro- inflammatory cytokines, such as chemokines, and anti-inflammatory cytokines, such as IL-10, may dictate the magnitude of the arthritis response. Taken together, our studies demonstrate that chronic joint inflammation is a multi-factorial response, which is dependent upon both pro-inflammatory chemokines, such as MIP- $1 \alpha$ and MIP-2, as well as regulatory cytokines, such as IL-10. This latter cytokine appears to be particularly important as a modulating cytokine during the progression of experimental arthritis and may play a similar role during the pathogenesis of autoimmune responses in human rheumatoid arthritis.

\section{Acknowledgments}

These studies were supported in part by National Institutes of Health grants 1POHL-46487, HL-35276, HL-31963, HL-31237, and HL50057.

\section{References}

1. Harris, E. D., Jr. 1990. Rheumatoid arthritis: pathophysiology and implications for therapy. N. Engl. J. Med. 322:1277-1289.

2. Stuart, J. M., A. S. Townes, and A. H. Kang. 1984. Collagen autoimmune arthritis. Annu. Rev. Immunol. 2:199-218.

3. Holmdahl, R., M. Andersson, T. J. Goldschmidt, K. Gustafsson, L. Jansson, and J. A. Mo. 1990. Type II collagen autoimmunity in animals and provocations leading to arthritis. Immunol Rev. 118:193-232.

4. Oppenheim, J. J., C. O. C. Zachariae, N. Mukaida, and K. Matsushima. 1991. Properties of the novel proinflammatory supergene Intercrine cytokine family. Annu. Rev. Immunol. 9:617-648.

5. Baggiolini, M., B. Dewald, and B. Moser. 1994. Interleukin-8 and related chemotactic cytokines CXC and CC chemokines. Adv. Immunology. 55:97-179.

6. Larsen, C. G., A. O. Anderson, A. Appella, J. J. Oppenheim, and K. Matsushima. 1989. Identity of the chemotactic cytokine for T-lymphocytes with neutrophil activating protein (NAP-1): a candidate interleukin-8. Science (Wash. DC). 243:1464-1466.

7. Schall, T. J., K. Bacon, K. J. Toy, and D. V. Goeddel. 1990. Selective attraction of monocytes and $\mathrm{T}$ lymphocytes of the memory phenotype by cytokine RANTES. Nature (Lond.). 347:669-672.

8. Tanaka, Y., D. H. Adams, S. Hubscher, H. Hirano, U. Siebenlist, and S. Shaw. 1993. T-cell adhesion induced by proteoglycan-immobilized cytokine MIP-

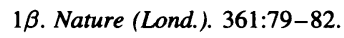

9. Taub, D. D., K. Conlon, A. R. Lloyd, J. J. Oppenheim, and D. J. Kelvin. 1993. Preferential migration of activated $\mathrm{CD}^{+}$and $\mathrm{CD} 8^{+} \mathrm{T}$ cells in response to MIP-1 $\alpha$ and MIP-1 $\beta$. Science (Wash. DC). 260:355-358.

10. Fiorentino, D. F., M. W. Bond, and T. R. Mosmann. 1989. Two types of mouse T helper cell. IV. Th2 clones secrete a factor that inhibits cytokine production by Th1 clones. J. Exp. Med. 170:2081-2095.

11. Hsu, D.-H., R. W. de Malefyt, D. F. Fiorentino, M.-N. Dang, P. Vieira, J. de Varies, H. Spits, T. R. Mosmann, and K. W. Moore. 1990. Expression of interleukin-10 activity by Epstein-Barr virus protein BCRF1. Science (Wash. DC). 250:830-832.

12. Moore, K. W., P. Vieira, D. F. Fiorentino, M. L. Trounstine, T. A. Khan, and T. R. Mosmann. 1990. Homology of cytokine synthesis inhibitory factor (IL10) to the Epstein-Barr virus gene BCRF1. Science (Wash. DC). 248:1230-1234.

13. Vieira, P., R. de Waal Malefyt, M.-N. Dang, K. E. Johnson, R. Kastelein, D. F. Fiorentino, J. E. de Vries, M.-G. Roncarolo, T. R. Mosmann and K. W. Moore. 1991. Isolation and expression of human cytokine synthesis inhibitory factor (CSIF/IL-10) cDNA clones: Homology to Epstein-Barr virus open reading frame BCRF 1. Proc. Natl. Acad. Sci. USA. 88:1172-1176.

14. de Waal Malefyt, R., J. Abrams, B. Bennett, C. G. Figdor and J. E. de Vries. 1991. Interleukin 10 (IL-10) inhibits cytokine synthesis by human monocytes: an autoregulatory role of IL-10 produced by monocytes. J. Exp. Med. 174:1209-1220.

15. Bogdan, C., Y. Vodovotz, and C. Nathan. 1991. Macrophage deactivation by IL-10. J. Exp. Med. 174:1549-1555.

16. Fiorentino, D. F., A. Zlotnik, T. R. Mosmann, M. Howard, and A. O'Garra. 1991. IL-10 inhibits cytokine production by activated macrophages. J. Immunol. 147:3815-3822.

17. Cassatella, M. A., L. Meda, S. Bonora, M. Ceska, and G. Constantin. 1993. Interleukin 10 (IL-10) inhibits the release of proinflammatory cytokines from human polymorphonuclear leukocytes. Evidence for an autocrine role of tumor necrosis factor and IL-1 beta in mediating the production of IL-8 triggered by lipopolysaccharide. J. Exp. Med. 178:2207-2211.

18. Kasama, T., R. M. Strieter, N. W. Lukacs, M. D. Burdick and S. L. 
Kunkel. 1994. Regulation of neutrophil-derived chemokine expression by IL-10. J. Immunol. 152:3559-3569.

19. Gárard, C., C. Bruyns, A. Marchant, D. Abramowicz, P. Vandenabeele, A. Delvaux, W. Fiers, M. Goldman, and T. Velu. 1993. Interleukin 10 reduces the release of tumor necrosis factor and prevents lethality in experimental endotoxemia. J. Exp. Med. 177:547-550.

20. Ishida, H., T. Muchamuel, S. Sakaguchi, S. Andrade, S. Menon, and M Howard. 1994. Continuous administration of anti-interleukin 10 antibodies delays onset of autoimmunity in NZB/W F1 mice. J. Exp. Med. 179:305-310.

21. Stuart, J. M., A. S. Townes, and A. H. Kang. 1982. Nature and specificity of the immune response to collagen in type II collagen-induced arthritis in mice J. Clin. Invest. 69:673-683.

22. Wooley, P. H., H. A. Luthra, J. M. Stuart, and C. S. David. 1981. Type II collagen-induced arthritis in mice. I. Major histocompatibility complex (I region) linkage and antibody correlates. J. Exp. Med. 154:688-700.

23. Trentham, D. E., A. S. Townes, and K. A. Kang. 1977. Autoimmunity to type II collagen: an experimental model of arthritis. J. Exp. Med. 146:857-867.

24. Williams, R. O., M. Feldmann, and R. N. Maini. 1992. Anti-tumor necrosis factor ameliorates joint disease in murine collagen-induced arthritis. Proc. Natl. Acad. Sci. USA. 89:9784-9788.

25. Wooley, P. H., J. Dutcher, M. B. Widmer, and S. Gillis. 1993. Influence of a recombinant human soluble tumor necrosis factor receptor FC fusion protein on type II collagen-induced arthritis in mice. J Immunol. 151:6602-6607.

26. Lukacs, N. W., S. L. Kunkel, R. M. Strieter, K. Warmington, and S. W. Chensue. 1993. The role of macrophage inflammatory protein 1 alpha in Schistosoma mansoni egg-induced granulomatous inflammation. J. Exp. Med. 177:1551 1559.

27. Davatelis, G., P. Tekamp-Olson, S. D. Wolpe, K. Hermsen, C. Luedke, C. Gallegos, D. Coit, J. Merryweather, and A. Cerami. 1988. Cloning and characterization of a cDNA for murine macrophage inflammatory protein (MIP), a novel monokine with inflammatory and chemokinetic properties. J. Exp. Med. 167:1939-1944.

28. Wolpe, S. D., and A. Cerami. 1989. Macrophage inflammatory proteins 1 and 2: members of a novel superfamily of cytokines. FASEB (Fed. Am. Soc. Exp. Biol.) J. 3:2565-2573.

29. Dugaiczyk, A., J. A. Haron, E. M. Stone, O. E. Dennison, K. N. Rothblum, and R. J. Schwartz. 1983. Cloning and sequencing of a deoxyribonucleic acid copy of glyceraldehyde-3-phosphate dehydrogenase messenger ribonucleic acid isolated from chicken muscle. Biochemistry. 22:1605-1613.

30. Hom, J. T., A. M. Bendele, and D. G. Carlson. 1988. In vivo administration with IL-1 accelerates the development of collagen-induced arthritis in mice. $J$. Immunol. 141:834-841.

31. Myers, L. K., K. Terato, J. M. Seyer, J. M. Stuart, and A. H. Kang. 1992 Characterization of a tolerogenic $\mathrm{T}$ cell epitope of type II collagen and its relevance to collagen-induced arthritis. $J$ Immunol. 149:1439-1443.

32. Goldblum, S. E., K. M. Wu, and M. Jay. 1985. Lung myeloperoxidase as a measure of pulmonary leukostasis in rabbits. J. Appl. Physiol. 59:1978-1985.

33. Stuart, J. M., and F. J. Dixon. 1983. Serum transfer of collagen-induced arthritis in mice. J. Exp. Med. 158:378-392.

34. Holmdahl, R., L. Jansson, D. Gullberg, K. Rubin, P. O. Forsberg, and L. Klareskog. 1985. Incidence of arthritis and autoreactivity of anti-collagen antibodies after immunization of DBA/1 mice with heterologous and autologous collagen II. Clin. Exp. Immunol. 62:639-646.

35. De Waal Malefyt, R., H. Yssel, M.-G. Roncarolo, H. Spits, and J. E. de Vries. 1992. Interleukin-10. Curr. Opin. Immunol. 4:314-320.

36. Holmdahl, R., J. Mo, C. Nordling, P. Larsson, L. Jansson, T. Goldschmidt, M. Andersson, and L. Klareskog. 1989. Collagen induced arthritis: an experimental model for rheumatoid arthritis with involvement of both DTH and immune complex mediated mechanisms. Clin. Exp. Rheumatol. 7:51-55.

37. Hom, J. T., V. L. Gliszczynski, H. W. Cole, and A. M. Bendele. 1991 Interleukin 1 mediated acceleration of type II collagen-induced arthritis: effects of anti-inflammatory or anti-arthritic drugs. Agents Actions. 33:300-309.

38. Hom, J. T., H. Cole, T. Estridge, and V. L. Gliszczynski. 1992. Interleukin1 enhances the development of type II collagen-induced arthritis only in susceptible and not in resistant mice. Clin. Immunol. Immunopathol. 62:56-65.

39. Piguet, P. F., G. E. Grau, C. Vesin, H. Loetscher, R. Gentz, and W Lesslauer. 1992. Evolution of collagen arthritis in mice is arrested by treatment with anti-tumour necrosis factor (TNF) antibody or a recombinant soluble TNF receptor. Immunology. 77:510-4.

40. Thorbecke, G. J., R. Shah, C. H. Leu, A. P. Kuruvilla, and Hardis. 1992. Involvement of endogenous tumor necrosis factor alpha and transforming growth factor beta during induction of collagen type II arthritis in mice. Proc. Natl. Acad. Sci. USA. 89:7375-7379.

41. Takai, Y., N. Seki, H. Senoh, T. Yokota, F. Lee, T. Hamaoka, and H. Fujiwara. 1989. Enhanced production of interleukin-6 in mice with type II collagen-induced arthritis. Arthritis Rheum. 32:594-600.

42. Cooper, S. M., S. Sriram, and G. E. Ranges. 1988. Suppression of murine collagen-induced arthritis with monoclonal anti- Ia antibodies and augmentation with IFN-gamma. J. Immunol. 141:1958-1962.

43. Mauritz, N. J., R. Holmdahl, R. Jonsson, P. H. Van der Meide, A. Scheynius, and L. Klareskog. 1988. Treatment with gamma-interferon triggers the onset of collagen arthritis in mice. Arthritis Rheum. 31:1297-1304.

44. Brennan, F. M., C. O. C. Zachariae, D. Chantry, C. G. Larsen, M. Turner, R. N. Maini, K. Matsushima, and M. Feldmann. 1990. Detection of interleukin 8 biological activity in synovial fluids from patients with rheumatoid arthritis and production of interleukin 8 mRNA by isolated synovial cells. Eur. J. Immunol. 20:2141-2144.

45. Koch, A. E., S. L. Kunkel, J. C. Burrows, H. L. Evanoff, G. K. Haines, R. M. Pope, and R. M. Strieter. 1991. Synovial tissue macrophage as a source of the chemotactic cytokine IL-8. J. Immunol. 147:2187-2195.

46. Seitz, M., B. Dewald, N. Gerber, and M. Baggiolin. 1991. Enhanced production of neutrophil-activating peptide-1/interleukin-8 in rheumatoid arthritis. J. Clin. Invest. 87:463-469.

47. Villiger, P. M., R. Terkeltaub, and M. Lotz. 1992. Production of monocyte chemoattractant protein-1 by inflamed synovial tissue and cultured synoviocytes. $J$ Immunol. 149:722-727.

48. Koch, A. E., S. L. Kunkel, L. A. Harlow, B. Johnson, H. L. Evanoff, G. K. Haines, M. D. Burdick, R. M. Pope, and R. M. Strieter. 1992. Enhanced production of monocyte chemoattractant protein-1 in rheumatoid arthritis. J. Clin. Invest. 90:772-779.

49. Rathanaswami, P., M. Hachicha, M. Sadick, T. J. Schall, and S. R. McColl. 1993. Expression of the cytokine RANTES in human rheumatoid synovial fibroblasts. J. Biol. Chem. 268:5834-5839.

50. Koch, A. E., S. L. Kunkel, L. A. Harlow, D. D. Mazarakis, G. K. Haines, M. D. Burdick, R. M. Pope, and R. M. Strieter. 1994. Macrophage inflammatory protein-1 alpha. A novel chemotactic cytokine for macrophages in rheumatoid arthritis. J. Clin. Invest. 93:921-928.

51. Mulligan, M. S., M. L. Jones, A. A. Vaporciyan, M. C. Howard, and P. A. Ward. 1993. Protective effects of IL-4 and IL-10 against immune complex-induced lung injury. J. Immunol. 151:5666-5674.

52. Marchant, A., J. Deviere, B. Byl, D. De Groote, J. L. Vincent, and M. Goldman. 1994. Interleukin-10 production during septicaemia. Lancet. 343:707708

53. De Waal Malefyt, R., J. Abrams, B. Bennett, C. G. Figdor, and J. E. de Vries. 1991. Interleukin 10 (IL-10) inhibits cytokine synthesis by human monocytes: An autoregulatory role of IL-10 produced by monocytes. J. Exp. Med. 174:1209-1220.

54. Leeuwenberg, J. F. M., T. M. A. A. Jeunhomme, and W. A. Buurman 1994. Slow release of soluble TNF receptors by monocytes in vitro. J. Immunol. 152:4036-4043.

55. Cassatella, M. C., L. Meda, S. Gasperini, F. Calzetti, and S. Bonora. 1994. Interleukin 10 (IL-10) upregulates IL-1 receptor antagonist production from lipopolysaccharide-stimulated human polymorphonuclear leukocytes by delaying mRNA degradation. J. Exp. Med. 179:1695-1699.

56. Wooley, P. H., J. D. Whalen, D. L. Chapman, A. E. Berger, K. A. Richard, D. G. Aspar, and N. D. Staite. 1993. The effect of an interleukin-1 receptor antagonist protein on type II collagen-induced arthritis and antigen-induced arthritis in mice. Arthritis Rheum. 36:1305-1314.

57. Katsikis, P. D., C.-Q. Chu, F. M. Brennan, R. N. Maini, and M. Feldmann. 1994. Immunoregulatory role of interleukin 10 in rheumatoid arthritis. J. Exp. Med. 179:1517-1527.

58. Quayle, A. J., P. Chomarat, P. Miossec, J. Kjeldsen-Kragh, Ø. Øfrre, and J. B. Natvig. 1993. Rheumatoid inflammatory T-cell clones express mostly Th1 but also Th2 and mixed (Th0-like) cytokine patterns. Scand. J. Immunol. 38:7582. 